\title{
THE URGENCY OF GEOGRAPHICAL INDICATION AS A LEGAL PROTECTION INSTRUMENT TOWARD TRADITIONALKNOWLEDGE IN INDONESIA
}

\author{
Pulung Widhi Hari Hananto*, Rahandy Rizki Prananda \\ Fakultas Hukum, Universitas Diponegoro \\ princedipojaya@gmail.com
}

\begin{abstract}
Traditional knowledge products characterized by geographical conditions are economically and spiritually valuable assets for the people of the area. Potential misleading of geographical indication goods requires a legal instrument that provides protection. Geographical Indication (GI) is one of the instruments of intellectual wealth that has its own characteristics. This study aims to examine the regulations of Geograpical Indication in the national and international levels, the implications of geographical indications for stakeholders and the ideal form of setting geographical indications in Indonesia. This study uses normative juridical methods and comparative studies. The results of the study show that the Gl's regulation applied in Indonesia adheres to a system of merging with brand regulation. The implications of Gl's registration bring a comprehensive impact on the economy and the legitimacy of traditional knowledge. After reviewing the comparison of the protection of geographical indications in Ethiopia and Jamaica, the authors recommend to separate the arrangements for geographical indications with brands (sui generis)
\end{abstract}

Keywords: Traditional Knowledge; Geographical Indication; Protection.

\begin{abstract}
ABSTRAK
Produk pengetahuan tradisional yang bercirikan kondisi geografis merupakan aset yang bernilai ekonomis dan spiritual bagi masyarakat daerah tersebut. Potensi penyalah gunaan terhadap barang indikasi geografis memerlukan suatu perangkat hukum yang bersifat memberikan perlindungan. Indikasi Geografis (IG) merupakan salah satu instrument kekayan intelektual yang mempunyai ciri khas tersendiri. Penelitian ini bertujuan untuk mengkaji pengaturan Indikasi geografis di tingkat nasional dan internasional dan implikasi Indikasi geografis terhadap para stakeholder dan bentuk ideal pengaturan IG di Indonesia. Penelitian ini menggunakan metode yuridis normative dan studi komparatif. Hasil penelitian menunjukan bahwa pengaturan IG yang diterapkan di Indonesia menganut system penggabungan dengan pengaturan merek. Implikasi pendaftaran IG membawa dampak komprehensif pada bidang ekonomi dan alat legitimasi terhadap pengetahuan tradisional. Berdasarkan perbandingan perlindungan Indikasi geografis di Ethiopia dan Jamaika, direkomendasikan untuk memisahkan pengaturan Indikasi geografis dengan merek (sui generis)
\end{abstract}

Kata Kunci: Pengetahuan Tradisional; Indikasi Geographis; Perlindungan.

\footnotetext{
* Corresponding Author
} 


\section{A. INTRODUCTION}

The complexity of legal protection issues against intellectual property rights in the era of globalization is followed by varied discourses. The birth of these problems is indirectly the result of the development of science, technology and human resources manifested in an innovation for the welfare of society. Taking into account the situation, the community is required to be critical and continue to test the determination of a product in order to produce intellectual work that dominates the market share of the economy. It becomes a trigger for every human being to try to use his creative power to the fullest by being supported by cultural support in competing as a superior resource in a particular field.

The initial motivation is to get individualistic economic benefits, the reality is not a little cause for social friction and mutual disrespect for one another. Contradictions that have occurred have triggered a very significant violation of the basic principles of intellectual property rights on intellectual works that have been created. The continuity of creativity competition in producing intellectual work that occurs without the existence of accommodating legal principles that are definite, independent and transcendent, indirectly causing polemic in the field of Intellectual Property Rights and transforming into a serious threat to intellectual products. Such conditions require the urgency of regulation, protection and respect for intellectual property rights in all infrastructures in all existing scope.

The definition of intellectual property rights is generally described as a right to wealth that arises or is born because of the results of human intellectual abilities and creativity. Intellectual property rights are categorized as rights to wealth considering that intellectual property rights ultimately produce intellectual works in the form of: knowledge, art, literature, technology and to make it happen requires a sacrifice of energy, time, cost and mind. The existence of sacrifice is marked as a value because it is felt that the existence of sacrifice has produced an intellectual work. If this is correlated with the economic benefits enjoyed, then the inherent economic value fosters the conception of property (property) of intellectual works earlier (Escudero, 2012). David Bainbridge interpret the Intellectual Property Rights as: "that area of law which is related to the creative rights or commercial reputation and good will". The conception laid out by David emphasizes more on legal protection and legal certainty for its protection. This is logical because examining the problem of Intellectual Property Rights in the end this community will lead to the legal concept of the values of an intellectual work (Riswandi, \& Syamsudin, 2004).

The relationship of a product, region and society describes an identity of images and symbols in a culture. The results of intellectual creativity created in a product, region and local community have been culturally and historically bound within a certain geographical boundary. This 
Law Reform

Volume 15, Nomor 1, Tahun 2019
Program Studi Magister IImu Hukum

Fakultas Hukum Universitas Diponegoro seems to signal that the identity of a society can be based on all forms and products of cultural activities that are sustainably and sustainably maintained in the social order system. Even in historical texts and cultural anthropology, a description of local products can be formulated as an identity that can project the cultural ethos of local indigenous people (Rustiala, \& Munzer, 2007). The differentiation of a product becomes an important instrument in describing the definition and recognition in juridical, economic and cultural aspects. Description of local products in an area serves to illuminate the identity of local residents. Product differentiation is an important means of attracting consumer interest in a market atmosphere surrounded by intense business competition.

The existence of geographical indications (which are then abbreviated as IG) in the modern era, not only symbolizes the characteristic of a particular region. But also emphasizes the traditional capabilities and processing techniques of a product that is characteristic of the region in question. As with brands, geographical indications have an important role in presenting a complete source of information and images of product guarantees to consumers about the quality and certain characteristics inherent in the product, which is a selling point in competition in the relevant market share. The quality of agricultural products and high-quality food ingredients is the result of local culture originating from a traditional production process that has been carried out for generations. In addition to the results of natural resources, geographical indication products also include handicrafts and industrial products that are characteristic of certain regions.

In the changing dynamics of the global economy, IG emerged as an important intellectual property tool (Mawardi, 2009). IG is contextually categorized as part of the creation of the community in a particular area while maintaining its distinctive character. Noting in the context of the meaning of geographical indications, geographic indications can be used as a functioning device to provide protection against traditional knowledge. But in reality, this is difficult to run smoothly and experience a number of obstacles. Developing countries do not have strong bargaining power at the level of international relations and lack of knowledge and awareness of the protection of intellectual property rights. This weakness led to the difficult position of developing countries in declaring and registering their products as geographical indications.

Traditional knowledge has become a new legal problem due to the absence of international and domestic legal instruments that can optimally provide traditional knowledge that is increasingly used by irresponsible parties. Modern IPR systems that have developed globally and uniformly have made it easier and enhanced the process of economic exploitation and erosion of indigenous cultures. This situation can be seen in the 
Law Reform

Volume 15, Nomor 1, Tahun 2019
Program Studi Magister IImu Hukum

Fakultas Hukum Universitas Diponegoro movement of hegemony and monopoly of multinational companies in the economic arena towards Genetic Resources and Traditional Knowledge

The conditions described above are also experienced by Indonesia as a developing country that has a large natural resource wealth with its unique characteristics in each region. In addition, the geographical indication products also made a symbol of identity from the symbolic Indonesian people. The product has also incised a reputation for cultural character of the local traditional community in creativity, taste and intention. Some examples of product geographical indication potential in Indonesia include Toraja Coffee from South Sulawesi, Munthok White Pepper from Bangla Island, Deli Tobacco from North Sumatra, Javanese Kapuk from East Java, BaliKintamani Coffeefrom Bali. These products are created based on human creativity based on cultural factors and local natural factors. Potential geographical indication products, it have a very significant value on the Indonesian economy in general and the local community in particular. According to Data from the Directorate General of Intellectual Property Rights of the Republic of Indonesia, there has been an increase in the number of registrations of Geographical Indications in the period 2008 to 2016 which stated that therewerea total of 46 IGs registered (List Of Registered Geographical Indication).

One of the geographical indication products that is very popular in Indonesia is Kintamani coffee. Kintamani coffee has characteristics derived from the region's natural factors, where these aspects provide special characteristics and qualities that distinguish it from other types of coffee so that this type of coffee is included in the requirements as a product of Geographical Indications. The concept of planting and cultivating kontamani coffee by local farmers is based on the synergy of knowledge and cultural values of the local community. The international community gives the embed name for Kintamani coffee, which is orange flavored coffee. The special designation is caused by the combination of orange and coffee flavors obtained not from an engineering stage. The taste of oranges in kintamani coffee is purely natural. Utilization of planting areas by farmers in Belantih which planted Arabica coffee seeds adjacent to the Kintamani citrus plantation which became the mainstay of Bangli Regency's agricultural products. If it is considered as a genetic engineering product in plants, then the element of accident done by farmers indirectly affects the taste of kintamani coffee.

The level of popularity and seeding of Kintamani Arabica Coffee with traditional elements has echoed up to the international level. This is evidenced by the many requests for exports to European countries, especially France. Dr. Massilimiano Fabian, Chair of the SCAB (Specially Coffee Association in Europe) and Dr. Vecenzo Sandalj, President of Associazione Caffe Trieste 
Law Reform

Volume 15, Nomor 1, Tahun 2019
Program Studi Magister IImu Hukum

Fakultas Hukum Universitas Diponegoro
Italia, even said that the copo product is very likely to increase its market share in the European region.

Based on the research he said, the taste of coffee produced from fermentation for 12 hours has a better taste and is suitable for European tastes, while the taste of coffee from coffee fermented for 36 hours is more suitable for the tastes of Americans, Japanese and Australians (Hananto,2014). The superiority of Kintamani's coffee product differentiation that comes from traditional knowledge that promotes culture and the secret technique of planting coffee bean cultivation development has made it a distinctive Indonesian product. This confirms that Indonesia is the only Kintamani coffee producing country. But on the one hand, in order to obtain better protection guarantees and provide commensurate income to producers, it is necessary to have a regulation and policy model for protecting kintamani coffee as a result of the wealth of traditional knowledge, in order to prevent a split, when the product is distributed and promoted in trade, where there will be a transfer of rights potentially carried out by interested persons, but do not have the right to market the product on the basis of profit.

Given the vast potential of legal implications for the indication of geography, it is necessary to regulate the recognition and appreciation of the results of one's creativity with a legal order called the intellectual property rights (IPR) or the Intellectual Property Right regime (Roisah, 2013).

This phenomenon can be interpreted as a polemic of Intellectual Property Rights by trending on geographical indications. The fame of the geographical indication products owned by a number of local communities in Indonesia requires legal protection that serves as a protective tool for commodity products from traditional knowledge from business competition that is fraudulent and accommodates the socio-economic interests of local communities to encourage and increase competitiveness of Indonesian products international trade. Some of researchs which related to the urgency of geographical indications has been done by several legal researchers before. However, the scientific articles have a focus on the subject matter of the study that is described in this journal.

The first study relates to the urgency of Geographical Indications on consumer protection in legitimate journals. In this study, the geographical indication function is intended to fulfill consumer rights, namely the right to comfort, security and safety in using goods and services. Specific information about an object is considered to be the key to guaranteeing consumer protection (Zakiyah, 2018). The second study was published in the legal dynamics journal. The article is entitled Legal Protection of the Potential of Geographical Indications in Brebes Regency in order to develop the Local Economic Community. This article tends to emphasize the registration of potential geographical indication products in the Brebes Regency region and their benefits to the economy 
of the local community (Asyifah, 2015).

The third study was published in an international journal article entitled How Does Australia Regulate The Use of Geographical Indications For Products Other Wines And Spirits. The focus of the issues discussed only explains $\mathrm{Gl}$ regulation in Australia which also accommodates trade products other than wine and spirits. However, it does not explain further the benefits of $\mathrm{GI}$ as a legal instrument that provides and does not specify the legal gap (Ayu, 2006). Other several previous studies discussed the how geographical indications (GIs) cannot deliver the protection for traditional knowledge that indigenous peoples seek (Frankel, 2011). Geographical Indication is an effective tool in protecting and rewarding not only the market potential of elite items but also the traditional knowledge associated with them (Kishore, 2018).. The potential impact of Geographical Indication protection to local economy (Sudjana, 2018). The legal protection for traditional knowledge could be realized by accommodating the traditional knowledge into the intellectual rights as a geographical indication and international recognition for the indigenous community communal ownership of the traditional knowledge. (Purwaningsih, 2014). The efforts to develop sui generis regulations for Indonesia traditional knowledge through sui generis system. (Rohani, 2015)

Traditional protection has become a very urgent issue for international communities, including
Indonesia, given that most of the economic benefits of international trade regarding indigenous (traditional) inheritance are less enjoyed by indigenous people. Based on the background of the legal issues outlined above, the authors would like to elaborate further into some formulation of the problems that will be studied in this article, namely: First, What is the formulation of legal arrangements for traditional knowledge based on Geographical Indications on national and international regulations. Secondly, what are the effectiveness of geographical indication arrangements in Indonesia and it implications for traditional knowledge. Thirdly, what is the legal protection model of traditional knowledge based on Geographical Indications that is ideal for application in Indonesia.

\section{B. RESEARCH METHODS}

The Types of Legal Research which used by the authors of this article is Doctrinal Legal Research. The method of approach to the problem used is normative juridical and Comparative study with descriptive qualitative research specifications, namely by analyzing and explaining qualitative data and then arranged in deductive thinking. The type of data used is Secondary Data which includes primary legal material (legislation related to Geographical Indications), Secondary legal materials (books, literature, journals, papers, proceedings related to the issue of Geographical Indications) and Tertiary Legal Materials (Legal 
Dictionary and English dictionary). The method of data collection applied by the authors is Literature Study.

\section{RESULT AND DISCUSSION}

1. Legal Protection Toward Traditional Knowledge Based on Geographic Indication

a. National Legal Instrument on Protecting Traditional Knowledge Through Geographic Indication

\section{1) The Law No.20 of 2016 Concerning}

\section{Trademark and Geographic Indication}

Regulation on geographical indications in Indonesia's nationa llegal system explicitly and in detail in the Act. No.20 of 2016 concerning Trademarks and Geographical Indications. The scope of the regulation of Geographical Indications in this legislation includes several things, among others: the period of protection, the supervision and guidance mechanism and the substance testing of a product to be categorized as a result of geographical indications. This regulation is a further battle of the previous Law, namely Law. No.15 of 2001 concerning Trademarks.

According to the provisions of Article 1 point 6 of the Law No.20 of 2016 concerning Trademarks and Geographical Indication, Geographical Indication is a sign that shows the origin of an item and I or product which due to geographical environment factors including natural factors, human factors or a combination of these two factors gives reputation, quality, and certain characteristics of the goods and / or products produced. The types of products that can be cultivated by local residents to be registered as a result of geographical indications include natural resources, handicrafts and industrial products.

The qualification of the specifications of a product or traditional knowledge can qualify as a geographical indication product if it fulfills a number of elements, namely: First, there is a sign taken from the name of the area which is a characteristic of a commercialized product. Second, a sign that shows the quality of the goods traded. Third, the quality of the product in question is strongly influenced by the natural environment, the social culture of the surrounding community and the technology used in the area concerned.

The existence of superior products in an area has an important meaning for the economic welfare of the surrounding community. Unique characteristics that are only owned by the product or item and not found in other places, although it is possible to come from the same composition of raw materials. Limited area coverage and strong market demand, have the potential to provide maximum benefits for residents of the regions producing these distinctive products.

The prescriptive approach toward GI protection is based on the registration legal process, which is a pre-condition for obtaining protection it benefits and concerning the recognition of the product (Belleti, 2011). Preservation of elements of uniqueness and special characteristics 
Law Reform

Volume 15, Nomor 1, Tahun 2019
Program Studi Magister IImu Hukum

Fakultas Hukum Universitas Diponegoro that only exist in the location producing the product requires a strong legal instrument as a basis for providing protection and accommodating the distribution of economic benefits to the surrounding community. Noting this, the existence of geographical indications as one component of Intellectual Property Rights (IPR) plays an important role in protecting a superior product. How to protect geographical indications, as stipulated in Article 53 of Law No. 20 of 2016 can be done by registration. The application for registration is carried out by the Minister, meaning that the party submitting the application for registration is the representative of the surrounding community who can take the form of an institution appointed by the entire community in the geographical indication area to represent the registration.

The community representatives can be in the form of producer association groups, cooperatives, local community geographical indication protection communities and the relevant Regional Government. Requests for registration of Geographical Indication products are submitted to the Directorate General of Intellectual Property Rights of the Republic of Indonesia. Provisions on the procedure for registration of administrative geographical indication applications are regulated in Government Ordinance No. 51 of 2007 concerning Geographical Indications. Judging from the aspect of object ownership, one geographical indication product cannot be owned by one person, but must be owned by all the people producing the geographical indication product collectively. Collective ownership shows differences in geographical indications with other types of intellectual property rights that can be owned individually. So that all people who are in the area of the geographical indication goods can use the Geographical Indication mark, if the goods produced are in accordance with the criteria required by the Trademark Law and Geographical Indications.

The next phase is the announcement. Information on the announcement of the results of inspection of goods registered aims to prevent the unilateral application of registration or acknowledgment of ownership of a geographical indication product that has been stated to be accepted by another party, as well as a legal sign of community ownership in the relevant geographical indication product area. Measure an object or product that has the potential to pass the selection as one of the geographical indications, according to the Indonesian Geographical Indication Book determined by the Directorate General of Intellectual Property Rights,including: (1) Product quality is maintained with good consistency; (2) Strong marketing system; (3) Able to provide market needs in sufficient quantities on an ongoing basis; (4) Effective and efficient management system; and (Commitment to comply with the provisions of regulations concerning Geography Indications.

By paying attention to the process of 
Law Reform

Volume 15, Nomor 1, Tahun 2019
Program Studi Magister IImu Hukum

Fakultas Hukum Universitas Diponegoro submitting an application for an indication of the geography above, it can be stated that the protection of indications of geography in Indonesia adheres to a constitutive system with the principle of first to file. The First to file principle means that legal protection will be given to the parties who first succeeded in registering geographical indications. The advantages of constitutive systems for protecting the rights of owners of geographical indications include: First, aspects of legal certainty related to ownership of Intellectual Property Rights. In this case, if there is a dispute about ownership claims of geographic indications as part of the IPR, then it can be known that the party with the most important rights is protected by law. Second, legal certainty in proof. Registration is the main strong evidence.

Although the constitutive system confirms the position of the owner of the geographical indication who first registered into a strong position, on the other hand, this system has the disadvantage of only registered geographical indication products that are entitled to legal protection. The logical consequence that can arise for the lack of a constitutive system is that there is an opportunity for other parties to take personal advantage and benefit economically from geographical indication products by registering them as trademarks. Not all results of traditional knowledge can be a product of geographical indications. According to the provisions of Article 56 paragraph (1) of the Law of Trademarks and Geographical Indications, the reason for the application for registration of geographical indications cannot be registered if: (1) Contrary to state ideology, legislation, morality, religion, morality and public order; (2) Misleading or deceiving society regarding reputation, quality, characteristics, source origin, process of making goods, and / or their uses; and (3) It is a name that has been used as a variety of plants that are used as similar plant varieties, unless there are additional equivalent words that indicate the same type of Geographical Indication.

Refusal of a geographical indication registration application can also be rejected by the Directorate General of Intellectual Property Rights of the Republic of Indonesia with a number of considerations consisting of: Documentation of geographical indication cannot be verified and the product has an overall similarity with the geographical indication product that has been previously registered. After the geographical indication product has passed and is officially registered by the Directorate General of Intellectual Property Rights office, then automatically the geographical indication product will get legal protection from the state. The period of legal protection against geographical indications is not limited as long as the GI rights holders are able to maintain, image, quality and characteristics which are the basis for the geographical indication given to objects that are registered continuously.

\section{2) Government Ordinance No.51 of 2007}


In order to apply Geographical Indication as a mechanism of protection against traditional knowledge, the Government of the Republic of Indonesia issued Government Ordinance No.51 of 2007 which regulates technical matters related to registration procedures for $\mathrm{GI}$ products that exist in certain areas in the territory of Indonesia along with other aspects from geographical indications. In the regulation of Law 15 of 2001 (the old Trademark Law), the limitation of the meaning of the sign only covers the name of the place or region, but does not indicate the place of origin of the goods protected by Geographical Indications. The intended items can be agricultural products, food ingredients, handicrafts or other items in accordance with the provisions.

Government Ordinance Number 51 of 2007 concerning Geographical Indications can be considered as the resolution of conflicts especially in the field of trade that occur in the community. As the implementing regulation of the Trademark Law Number 15 of 2001, especially Article 56 concerning Geographical Indications, Government Ordinance Number 51 of 2007 is issued which is expected to be used as an guideline for implementing registration of Geographical Indications. Several articles have been ratified to regulate the systematic registration of Geographical Indications in Indonesia so that there is an orderly direction of the economic system in Indonesia.

Based on Government Regulation No. 51 of 2007 , legal protection of geographical models can be provided after registration. The existence of geographical indications aims to ensure legal certainty for the protection of wealth and traditional knowledge. the protection period for geographical indications can last as long as the characteristics and I or quality used as the basis for their registration still exist. The characteristics and determination of benchmarks in setting basic standards in the registration of geographical indications is explained as rules of operational standards, which include information about geographical location, natural and human factors that affect good quality or characteristics. In operational standards also attach information regarding maps of regions / regions, history and tradition, processing, good quality testing methods, and network of facilities used. Standard operational rules are prepared by local community groups where goods are produced.

The owner of a Geographical product indication and a group of people in the area where the goods are produced. Both have the competence to preserve, maintain and use geographical indications in connection with daily economic needs. Meanwhile, producers who are able to produce Geographical Indications goods, which are in accordance with the criteria set out in the Geographical Indication guidebook and comply with all provisions in it, have the right to use geographical indication products, after they register themselves as users of geographical indications on Office of the Directorate of Intellectual Property 
Rights. The results of foreign IG products can also be registered in Indonesia. In order to pass the substance test and be accepted in the registration process, the conditions that must be fulfilled by the foreign IG product are that the item must have been recognized and registered officially in the provisions of the country of origin regulations. Registration of IG products in Indonesia is carried out by the Directorate General of Intellectual Property Rights. This institution is supported by the Geographical Expert Team. The seven members from the Ministry of Agriculture, the Ministry of Law and Human Rights, the Ministry of Industry and the Ministry of Industry and the Ministry of Maritime Affairs and Fisheries.

Indonesia is an archipelagic country that is rich in knowledge, traditions and culture and a tropical climate that produces various types of good products with diverse cultures. Where in each region there are many inheritances has the potential to produce products in the form of goods derived from the knowledge of the surrounding community. Sociological excellence is a high value inheritance that comes from a traditional heritage that has been handed down in Indonesian society, especially food and handicrafts. The dominance of traditional-based products also shows knowledge in the present. The issuance of Law No. 20 of 2016 (Trademark and GI Law) and Government Ordinance of the Republic of Indonesia No.51 of 2007 is a manifestation of the Indonesian Government's concern in protecting cultural heritage and traditional knowledge of local communities.

\section{b. International Legal Instrument On Protecting Traditional Knowledge Through Geographic Indication}

\section{1) Paris Convention 1883 For Protection IndustrialProperty}

The existence of the Paris Convention as a legal instrument of the first multilateral treaty in accommodating the protection of intellectual property rights, especially indications of sources or assessments of origin in member countries, based on legal regulations and customary practices of each country. The Paris Convention stipulates that "indication of source or judgment of origin" is a legal subject that can be protected. However, the legal protection offered is limited to guaranteeing certain protective measures in a specific or broad scope, but only for IG use that is wrong or misleading, not general IG use. In addition, the Paris Convention does not define "indications of sources or statements of origin" or introduce international standards for their protection.

Article 10 The Paris Convention prohibits misuse of indications of regions when accompanied by trade names that are wrong, fictitious, or deceptive. This provision also mandates the seizure of goods identified with false indications of origin when: "When every producer or trader ... is involved in the production or manufacture or sale of these goods." This prohibition was reinstated in 1958, 
when article 10 was internalized into the Paris Convention. According to the article, the indication categories that "can mislead the public regarding the nature, manufacturing process, characteristics, suitability for their purpose, or quantity," must be prohibited as an act of unfair competition.

\section{2) Madrid Agreement 1891 for The Repression of False or Misleading Indications of Source Goods}

In the provisions of the Madrid Agreement 1891 only focused on limited legal protection and accommodated a number of specific provisions that regulate a number of repressive actions against signs of misuse or misuse of sources. In the provisions of article 1 states that: "prohibited the use of false and deceptive indications of sources and mandated seizures of goods bearing such indications". The context of a deceptive understanding occurs when certain types of geographical indications are in two countries. However, only one country uses that name as a source of goods...if another country pioneers the use of product names that are geographic indications in order to obtain economic benefits for the reputation created by the first country, then the action is categorized as misleading in the Madrid Agreement.

The Provisions inside the Madrid Agreement of 1891 to provide additional levels for member states and countries that should not be excluded for indications of origin for other goods. The Safety
Agreement granted was stronger than the Protection of Paris 1883, provided only States helped provide ratification of this agreement.

\section{3) Lisbon Agreement 1958 for the protection of Appellations of Origin and their International Registration}

Lisbon Agreement 1958 was regulating the definition of the term "geographic name of country, region, or locality, which serves to designate a product originating there, or which is essentially due to the geographical environment, including natural and human factors". This agreement obliges its member countries to protect the mention of authenticity that has been registered in the form of seizure or imitation of another member country registered with WIPO. The main objective of the Lisbon Agreement was 1958 to accommodate the needs of international legal protection instruments and facilitation facilities for Gls such as the Appellation of Origin in several countries outside the country of origin of the geographical indication, where the protection was realized through a single registration system at the WIPO International Bureau.

\section{4) Trade Related Aspect of Intellectual Property Rights}

GI regulation in TRIPS is described in Article 22 number 1 which states that: "A product is an indication that identifies an item originating from a member area, or region or locality in that area, 
Law Reform

Volume 15, Nomor 1, Tahun 2019
Program Studi Magister IImu Hukum

Fakultas Hukum Universitas Diponegoro where quality, reputation or other characteristics are basically caused by its geographical origin. "The use of designation for geographical indication products. can refer to a symbol or point to a place, without the need to use additional local names that are popular in the local area. That is enough to show specific identification of a geographical indication product.

The definition of several crucial words in article 22 is the word phrase in the dispute or has not been the subject of interpretation in the context of the WTO. Indications, territories, represent the quality, reputation, characteristics and geographical indications can be interpreted in a variety of ways by WTO members. For example, there are differences of opinion about whether the reference to "territory" means that "Kopi Kintamani", for example (Hananto, Geographical Indication as a Tool to Protect Indonesian Herritage: Lesson From Bali Kintamani Arabic Coffee Case. , 2014), can receive GI Protection. According to those who oppose the idea, GI refers almost exclusively to products with local, not national attributes.

Obviously, in accordance with the definition in article 22.1, indications that do not connote quality, reputation or characteristics are not $\mathrm{GI}$ TRIPS (Hananto, Geographical Indication as a Tool to Protect Indonesian Herritage: Lesson From Bali Kintamani Arabic Coffee Case, 2014). Correlation of the relationship between quality, reputation, or product characteristics and the area where the product is produced is an important factor. For example, local soil or fungi can contribute to the taste, texture or color of special foods. The relationship between products and regions must tell consumers about some important characteristics of the product which are the ingredients in the decision to buy goods. On the other hand, we must understand that the definition and protection of existing Geographical Indications based on Traditional Knowledge or food is made into the same interpretation. debated or to expand or expand the TRIPS scheme. Today the recognition and protection of food are very identical or parallel to TRIPS (post- DOHA) which adds protection to wine and alcoholic beverages. Even though the TRIPS agreement distinguishes trademark and geographical indications as different Intellectual Property forms, GI arrangements are submitted to each of the countries concerned, whether the arrangements are combined together with brand arrangements and or are regulated separately (sui generis).

Characteristics of geographical indications that are different from other forms of IPR, in TRIPS there are a number of characteristics of Geographical Indications, among others: First, geographical naming is not absolute, because naming can use non-geographical names. must refer to the area administratively but only based on the factual state of the region. Third, GI ownership rights are not individual but communal. Fourth, the completeness of the fulfillment of the quality, characteristics and reputation of goods is only 
categorized as an alternative, an item can be qualified as a GI sufficiently fulfilling one of these aspects.

\section{The Implications for Protection of Geographical Indications on Traditional Knowledge Based Products}

The legal substance in the field of Geographical Indication is very important in determining the legal protection of products protected by such Geographical Indications. The importance of legal substance was formulated by Bernard L. Tanya, Yoan N. Simanjutak and Markus $Y$. Hage is a rule of the game that places law as the main element in system integration. This was also supported by Steeman, who confirmed that what formally constitutes a society is the general acceptance of normative rules of the game. It is this normative pattern that must be seen as the most core element of an integrated structure. In this Bredemeier framework, the law is used to resolve conflicts that arise in the community. Legal protection of Geographical Indications in its relation is based on rules that apply internationally and are adapted nationally to each country that regulates geographical Indications. Based on juridical normative, Indonesia can be said to adhere to a geographical indication protection system that is based on the Brand-based Trademark Law. Therefore, the geographical indication arrangement in Indonesia is regulated The Law Number 20 of 2016 concerning Trademarks and implementing regulations of the Republic of Indonesia Government Regulation Number 51 of 2007 concerning Geographical Indications.

The context of the $\mathrm{GI}$ definition in Article 1 Number 6 of Act Number 20 of 2016 is a sign indicating the area of origin of an item and / or product which due to geographical environment factors including natural factors, human factors or a combination of these two factors gives reputation, quality, and certain characteristics of the goods and I or products produced. GI objects should be limited to natural products because of the uniqueness, privilege, or superiority of the product compared to other similar products born from the earth (geo) where the product originated. Therefore, the regulation of IG must reflect the natural results of a particular region and the special quality of the product concerned.

In this legal concept, arrangements for the protection of geographical indications in Indonesia can only be given to goods (good), not including services. To obtain geographical indication protection, an item must meet the main requirements, consist of:

a) There are applicants for registration of geographical indication protection (Article 53 paragraph (2) of Law No. 20 of 2016);

b) Goods for obtaining geographical indication protection must be registered with the Directorate General of Intellectual Property Rights of the Ministry of Law and Human Rights (Article 53 paragraph (1) of Law No. 20 of 2016)

c) Goods must fulfill 3 (three) main elements, namely having signs, geographical environmental factors and quality of goods 
Law Reform

Volume 15, Nomor 1, Tahun 2019
Program Studi Magister IImu Hukum

Fakultas Hukum Universitas Diponegoro
(Article 53 paragraph (3) Law No. 20 of 2016)

d) The applicant must make a code of practices for the goods to be requested (Article 5 paragraph 3 Governance Ordinance No. 51 of 2007)

The relation with products from Kintamani's traditional knowledge and traditional culture in order to obtain geographical indication protection, must fulfill the main requirements above, along with the main elements of legal protection of geographical indications that must be fulfilled by a product from the wealth of traditional communities include:

\section{a. Holders of Geographical Indication Rights}

The central role in registering Geographical Indications is the applicant's party. Indications can submit applications for registration to the Directorate General of Intellectual Property Rights of the Ministry of Law and Human Rights by the institutions represented by producers, namely indigenous communities incorporated in the Society for the Protection of Geographical Indications. The Society for the Protection of Geographical Indications qualifies as the applicant, because having a direct interest in the protection of geographical indications is the producer. The idea of the protection of geographical indications that emerged from producers, which in the future is expected to have an impact on rural community development (rural development),especially in this case is the indigenous community or Subak Abian.

Article 53 paragraph 3 of Law Number 20 Year 2016 concerning Trademark and Article 5 paragraph 3 Governance Ordinance No 51 of 2007 concerning Geographical Indication, which states that geographical indications are protected after being registered on the basis of an application submitted by an Institution representing the community in the area producing goods concerned, consisting of: natural resources, handicrafts; or industrial products. Limitation of the determination of the institution representing the community in the area that produces the beaver is the institution that is authorized to register geographical indications and the institution is a government institution or other official institution such as cooperatives, associations and others.

According to the explanation Governance Ordinance 51 of 2007, the definition by institutions includes but is not limited to cooperatives, associations or foundations whose members are local producers. Regarding the institution given authority as referred to in Article 53 paragraph 3 letter (b) of Law No. 20 of 2016 and Article 5 paragraph $3 \mathrm{~b}$ are government institutions in the area in charge of goods submitted for applications, such as regional governments both at the provincial and district / city levels. Based on the above provisions implicitly there are 3 (three) parties who can submit applications for geographical indication protection, namely government, institutions representing producers and consumer groups. If viewed from the purpose of geographical indication protection, regarding the subject matter of the applicant for registration of geographical indications 
it has its own consequences for the continuity of utilization of geographical indications, namely as follows:

\section{1) The Government}

The central and regional governments act as applicants in the registration of geographical indications that are more likely to be conservation efforts or protection of cultural heritage contained in geographical indications. As is known, reputation, quality and characteristics of goods that are protected in geographical indications are formed from local cultural heritage that has been carried out continuously, such as traditional knowledge which has an important role in shaping the reputation of geographical indication goods as national identity. The advantage of the government as an applicant in the registration of geographical indications and the owner of geographical indication rights, namely the government is the subject of applicants who are not vulnerable to dissolution, when compared to institutions representing producers and groups of consumers who are vulnerable to dissolution.

The broad influence of Gls on the protection of traditional knowledge is a special characteristic of local local communities, indirectly influencing regional economic development carried out through partnerships between the relevant local government, business actors and local communities to realize community welfare through opening employment and increasing income native area.
Taking into account this issue, it is necessary to have a set of regional government policies that are able to synergize well with $\mathrm{Gl}$ regulations at the national level.

\section{2) Institutions whose representing producers}

The Association of $\mathrm{Gl}$ producers as the party submitting the application for registration of geographical indication protection, is directly related to the protection of geographical indications. The producer is the party that is the most disadvantaged, if there is a partnership with a reputation without the right to produce goods. In addition to producers, losses also have a broad impact on the parties involved in the supply chain such as raw material suppliers, traders, whole sellers, retailers, etc., so that losses will have a broad impact on the socio-economic conditions of the community. Therefore, the main focus of the protection of geographical indications lies with the producer, so that the property rights of the geographical indications held by the institution representing the producer, including those involved in the production chain, will be more beneficial for the sustainability of their business.

. This causes the protection of geographical indications to have no impact on the socioeconomic conditions of the community where the geographical indication is located. The form of legal protection for the geographical indication product will not work properly, if there is an act of clamping down on the geographical indication product, the 
Law Reform

Volume 15, Nomor 1, Tahun 2019
Program Studi Magister IImu Hukum

Fakultas Hukum Universitas Diponegoro owner is inactive, so that he will not be able to effectively supervisor sue the perpetrator of the reputation without that right

\section{3) The Consumer}

The benefits of GI play a very important role as a marketing tool in strengthening the geographical product position in the market and driving new market expansion in order to capture consumers of these products. A high level of consumer confidence indirectly makes consumers willing to pay high prices because of the satisfaction factor for product quality and the unique traditions contained in it. The group of consumers who submit applications for registration of geographical indication protection, if associated with the purpose of geographical indication protection, actually consumers have a direct connection because with the protection of geographical indications, consumers have been protected from confusion and misdirection of fake geographical indication products. Actually, the authority of the consumer to apply for registration of geographical indications is not appropriate because consumers do not have an interest in producing and marketing products, but consumers only have the role of consuming the product, in the hope that the products consumed are in accordance with the quality they expect.

Consumers have no interest in switching to the producer, but only expect a guarantee that the products they buy are in accordance with the characteristics, quality and reputation of a product labeled with geographical indications. So the difference between producers and consumers in geographical indication protection, according to Miranda Risang Ayu lies in the form of protection, for producers is active protection and consumers are passive protection (Ayu, 2006). The following are the advantages and disadvantages for each subject applying for Geographical Indication.

\section{b. GI's Signature}

Other items which are derivatives of the product do not include items requested for protection. For example, is the product registration for the geographical indication of Kintamani coffee. The name of the geographical indication requested for protection is "Kintamani Coffee Bali", is coffee beans and their products are produced from the Bangli Regency and Kintamani Districts. The use of the name GI may only be used against Kintamani Coffee which means it is planted and produced in the Kintamani region as required in the requirements book. While the proposed protection is the name "Bali Kintamani Coffee", so that the words "Kintamani", "Bali" or "Coffee" are not considered as a form of illegal abuse or imitation and can be used by producers instead of Bali Kintamani Coffee. Besides that, the Geographical Indications of Bali Kintamani Coffee also use logos that contain images and writings, namely images of Gunung Batur, Temple of Bali, pictures of coffee beans and writing of Kintamani Coffee Bali.

According to the provisions of Article 1 point 
Law Reform

Volume 15, Nomor 1, Tahun 2019
Program Studi Magister Ilmu Hukum

Fakultas Hukum Universitas Diponegoro
6 of the Law. No.20 of 2016 concerning Trademark and $\mathrm{Gl}$ context of geographical indication as protected legal object is considered as a sign that shows the origin of the product concerned based on natural, human or alert factors between the two which indirectly provide quality, technique and reputation on products produced in the area certain. The variety of goods that can be qualified as a product of a Geographical indication can be in the form of natural resources, industrial products and handicrafts that reflect the specific characteristics of the area of origin. While protecting the interests of the region producing the typical product. In addition, protection of Geographical Indications is also beneficial for consumers because it guarantees product quality (Yessiningrum, 2015). Market failure in building the image of a product in a Geographical Indication product is caused by asymmetrical information about the uncertainty of the quality of the product being transported, so a sign is needed to overcome the ambiguity of the quality of goods as collateral), as well as the brand reputation, etc.

Information obscurity in the promotion of geographical indication products between sellers and buyers has the potential to give a bad predicate for geographical indication goods as a result of the uncertainty of the quality of the products being traded. Geographical indications on a product of traditional knowledge, for example, kintamani Bali arabica coffee is a sign (indication) that connects goods of a certain quality, characteristics and reputation based on regions of geographical origin.
So that Geographical Indications are seen as playing an important economic role, namely giving a sign for consumers to get the expected goods.

\section{The Ideal Legal Protection of GI inIndonesia a. Example Cases on Another Country 1) J amaica Blue Mountain Coffee}

Jamaican choose to use Gl's and certifications marks to protect Jamaican Blue Mountain Coffee instead of the trademark route Ethiopea followed. This was done beacuse a GI provides a spesific link between the coffee grown and the Blue Mountain of Jamaica (Walker, 2009). In 1948 the coffee industry board of Jamaica was formed to oversee the production of coffee within industry. The Goal of this board are to develop the coffee industry, promote the welfare of Industry workers and make recommendations to the government.

In 1948, the Government of Jamaica formed the Coffee Industry Council which was tasked with supervising the coffee plant production business, the Coffee Industry Council was assigned to be actively involved in distributing coffee plants from the start of the nursery, registration and supervision of agricultural lands, empowering farmers in processing coffee plants as well as licensing arrangements and merchants. The government also carried out physical supervision of coffee agricultural products to be sold overseas through coffee residue testing, coffee quality test quality certification for coffee packaging management. The 
Law Reform

Volume 15, Nomor 1, Tahun 2019
Program Studi Magister IImu Hukum

Fakultas Hukum Universitas Diponegoro coffee business development program is funded by the Government through income from the tax sector. Currently there are 7600 coffee farmers with $92 \%$ of them working on five acres of land or less (Walker, 2009). A one pund bag of roasted jamaican Blue Mountain is selling arround for about \$50 per pound (Tomothy, 2007).

Under the Geographical Protection Act of the Jamaica Blue Mountain Coffee product, it was recognized as one of the geographical indication assets in 2004. At present, Jamaica Blue Mountain Coffee Products are registered (marks and trademarks) in 61 countries in the world. The license to use the geographical indications for these products is increasingly difficult to obtain throughout the world, due to the high registration and coercion costs. This sign is one example of best practice from a country in developing important commodities into a product that is successful in the market.

The protection and development model of $\mathrm{GI}$ products in Jamaica received contrasting responses from Ethiopia. Ethiopia argues that the conditions experienced by its country allow for the application of $\mathrm{Gl}$ protection methods. The quantity of farmers and the potential of products in Ethiopia is far more manageable. Lower profits for farmers will result from increased administrative costs. Although it has the potential to raise costs, it should be noted that the area of land used by producers in Jamaica is smaller. The implementation of $\mathrm{GI}$ protection systems in Jamaica on the one hand will spend more time, but the increase in costs can be overcome by rising prices provided through licenses or trademarks.

\section{2) The Starbucks Case inEthiopia}

Coffee is a leading commodity in Ethiopia. it produces about $5 \%$ of world production and more than $30 \%$ of Sub- Saharan Africa. More than one million small-scale producers generate $9 \%$ of output and more than 10 million Ethiopians are part of direct or indirect coffee production (Basti, \& Matteucci, 2007) . Ethiopia began registration of international trademark registration in 2004. Coffee trademarks were submitted for registration between Yirgacheffe, Sidamo and Harrar. This coffee edition trademark has been announced in 28 countries around the world. The reason for the Ethiopian Government was to create local coffee selling value by differentiating prices from the prices determined by the highly volatile New York trade exchange. This step is expected to be able to bring economic benefits to farmers and local distributors.

The strategy was implemented in the form of a single fee royalty-free license. But the purpose of this policy has not yet materialized even though high retail prices on branded coffee already exist. Coffee farmers receive as low as $2 \%$ for export prices which is barely enough to cover costs, and as a result some coffee farmers withdraw their crops to sell narcotics for greater profits (Basti, \& Matteucci, 2007) . In 2007, it was reported that Ethiopian specialty coffee such as the Sidamo brand was valued at around $\$ 26$ dollars per pound 
Law Reform

Volume 15, Nomor 1, Tahun 2019
Program Studi Magister IImu Hukum

Fakultas Hukum Universitas Diponegoro
(162 oz) at Starbucks because of their reputation, while Ethiopian coffee farmers received around \$ 1.35 per pound for seeds (Garamfalvi, 2007). Currently Ethiopia Sidamo Coffee sells for $\$ 15$ per oz on the Starbuck website.Forcomparison, $\$ 17.34$ will buy three packs of $80 z$ Brand Coffee folgers jars.

The EIPO (Ethiopian Intellectual Property Right) released a list of trademarks and initiated the initial steps of applying for licenses for the use of the Ethiopian coffee trademark in 2004. The Ethiopian government initiative received financial support from the UK Department of International Development. So it was noted that more than 60 foreign companies have signed licensing agreements with Ethiopia. The following year, the Ethiopia Government submitted a request for registration of the Yirgacheffe and Harar Coffe trademark to the United States Patent and Trademark Office (USPTO). But at the same time, Starbucks has applied for a trademark registration in the name of "ShirkinaSun-Dried Sidamo". Starbucks also insisted on refusing to withdraw its registration. Responding to this, the Ethiopian Government appealed to the United States Patent and Trademark Office (USPTO) for alleged violations of the use of trademarks in the common law right, eventually starbuck revoked his application but starbuck still insisted on using the brand want to be registered by the Ethiopian Government

Oxfam America conducted a public campaign on the actions of starbuck who misused the Ethiopian trademark. The impact was that Starbucks was the topic of discussion on worldwide news coverage of the trademark infringement issue of the Ethiopia' GI. Eventually due to the huge wave of pressure from the international community Starbucks signed a licensing agreement with Ethiopia. Ethiopia has won IP rights over its special Geographical indication in 2007 (Garamfalvi, 2007). Imposition sanction for stopping production of starbucks have the potential to cause investment and profit losses. As of consequences Ethiopia does not ask for royalties on the license and only charges a fixed fee to Starbucks.

\section{b. The Ideal IG's as Protections Tool of Traditional Knowledge}

The model of $\mathrm{Gl}$ regulation at the national level that is applied to each country consists of two types, namely:

First, the GI regulation model that integrates a regulation with a trademark. Countries that regulate Gls with Trademarks into the same law, Ways of legal protection against Gls are carried out by collective or certification licenses. The Country that apply trademark system in protecting GI just use the resources which already have been using for trademark system for application, registration, opposition, adjudication, cancellation and enforcement. Then the system accommodates GI that are not just place names, but also sign, like words, slogans, designs, dimensional marks, colors 
Law Reform

Volume 15, Nomor 1, Tahun 2019
Program Studi Magister IImu Hukum

Fakultas Hukum Universitas Diponegoro or even sounds and scents (Geographical Indication and TRIPS : 10 years Later, ,2007).

Second, GI regulation through the Sui Generis system which indirectly results in logical consequences for $\mathrm{GI}$ protection by special methods and mechanisms that are separate from the arrangements for protection of other types of IPR. Countries that implement the Sui Generis system that provides $\mathrm{GI}$ registration services, the producers have no difficulty in protecting their GI products. This system has been widely used by many countries to protect $\mathrm{GI}$ wealth for centuries.

The Regulation of protection toward $\mathrm{GI}$ is applying in Indonesia, The Law. No.20 of 2016 concerning Trademarks and GIs adheres to a regulatory system integrated with trademarks. Integration of regulations between brands and GIS on the one hand has not had a positive impact on the provision of $\mathrm{GI}$ protection. The legal protection provided is only temporary does not provide longterm protection. It would be better to arrange GI protection to be accommodated into a special regulation that is specific (sui generis). The reason the authors recommend that the regulation of GIs on traditional knowledge includes: (1) $\mathrm{GI}$ is a special form of IPR that serves as a tool to give protection to traditional knowledge assets which are important assets in the economic development of a country. Sui generis arrangements can potentially produce an effective impact on the protection of traditional knowledge up to the realm of its postulates; (2) Legal Protection of Gls stipulated in the Act. No.20 of 2016 is not suitable to be applied in providing guarantees against traditional knowledge from potential misuse of foreign parties. Other IPR models are very suitable and effective in safeguarding their economic rights, but as we know GIs have their own characteristics that are holistic (including spiritual aspects and reflection of the identity and integrity of the community).

This article view, the Indonesian Government should be able to consider the GI regulation options in a generic manner. The values of collectivity, pluralism and communalism that exist in Indonesian society are very not in accordance with the individualistic concept in the current reguals. So that the application of an integrated GI legal system can be a problem in its implementation.

\section{CONCLUSION}

GI has its own differences with other forms of IPR in a system of wealth protection against traditional knowledge. The communalistic GI philosophy that lives in the local communities around the IG is considered capable of guaranteeing the protection of economic rights (exclusive rights) for producers of traditional knowledge products that describe the identity of the local community. Indirectly it can be said to be able to protect cultural heritage and traditional knowledge that is owned by the community.

The urgency of the separation of GI (Sui Generis) arrangements in national law. This is because the characteristics of protection provided 
Law Reform

Volume 15, Nomor 1, Tahun 2019
Program Studi Magister IImu Hukum

Fakultas Hukum Universitas Diponegoro in Law No. 20 of 2016 have differences with traditional knowledge, so that they have not fully guaranteed comprehensive protection. In addition, the establishment of strong technical regulations and mechanisms is also needed to be able to work together in safeguarding the interests of the rights of the people who produce GI products.

\section{REFERENCES}

\section{BOOK}

Ayu, Miranda R. (2006). Memperbincangkan Hak Kekayaan Intelektual Indikasi Geografis. Bandung: PT ALUMNI.

Belleti, Giovani et.al. (2011). The Effect of Protecting Geographical Indicatios: Ways and Means of Their Evaluation. Berne: Swiss Federal Institute of Intellectual Property.

Riswandi , Budi Agus., \& Syamsudin, M. (2004).

Hak Kekayaan Intelektual dan Budaya Hukum. Jakarta: PT. Raja Grafindo Persada.

Rotstein, F. (2009). Sidamo:a Teaching Case for WIPO. Australia: Melbourne Law School.

Sudaryat et al. (2010). Hak Kekayaan Intelektual.

Oase Media : Bandung.

Tanya, Bernard L., Simanjutak, Yoan N., \& Hage, Markus Y. (2010). Teori Hukum Strategi Tertib Manusia Lintas Ruang dan Generasi. Yogyakarta :Genta Publishing.

\section{J OURNAL \& WORKING PAPER}

Bastin, Anne., \& Matteucci, Nicola. (2007). Finacing Coffee Farmers in Jimma Zone. Ethiopia:
Challenge and Opportunities, Vol.9, (No.39), p.265

Hananto, Pulung W H. (2014). Geographical Indication as a Tool to Protect Indonesian Herritage: Lesson From Bali Kintamani Arabic Coffee Case. Journal of Intellectual Property Law And Practice. National University of Malaysia; p.4.

Kishore, K. (2018). Geographical Indications in Horticulture: An Indian Perspective. International J ournal of Intellectual Property Rights, Vol. 23, (J uly-S eptember), p.159-166. Mawardi, S. (2009). Establishment of Geographical Indication Protection System in Indonesia, case in Cofee, World wide Symposium on Geographical Indications, the World Intellectual Property Organization, Sofia, June .p.4

Purwaningsih, E. ( 2014). Disclosure of Origin pada Pengakuan dan Publikasi Tradisional Knowledge dalam Upaya Perlindungan Hukum. J umal Hukum lus Qius lustum, Vol. 21, (no.2), p. $272-292$.

Rohani. (2015). The Law Protection of Traditional Knowledge throught Sui Generis Law. Fiat J ustisia J urnal IImu Hukum, Vol.9, (No. 4), p. 428-449.

Rustiala, Kal., \& Munzer, Stephen R. (2007).The Global Struggle Over Geographical Indication. The European Journal of International Law, Vol. 18, (No. 2), p.9 .

Sudjana. (2018). Implikasi Perlindungan Indikasi 
Geographis Menurut Undang Undang Nomor 20 Tahun 2018 Terhadap Ekonomi Lokal. J urnal Veritas Et J ustisia, Vol. 4, (No.1), p. 30-58.

Walker, L. (2009). J amaica Blue Mountain: Quality and Geographical Origin, Presentation at the Workshop on the Challenge Relating to $G$ is for ACP Countries, 20. March, 24- 27, 2009. p.21.

Tomothy J. Castle., \& Joel Star. (2007). Ethiopia's Branding Battle, tea and Coffee. Trade J. April, p.27

Yessiningrum, Winda R. (2015). Perlindungan Hukum Indikasi Geografis sebagai Bagian dari Hak Kekayaan Intelektual. J urnal IUS Kajian Hukum dan Keadilan, Vol.III, (No.7), p.44.

Frankel, S. (2011). The mismatch of geographical indications and innovative traditional knowledge. Jornal of Promotheus Critical Studies in Innovation, Vol, 29, (No.3), p.1-21.

Roisah, K. (2013). Membangun Prinsip-Prinsip Perlindungan Hukum Kekayaan Intelektual Berbasis Kearifan Lokal (Studi Perlindungan Hukum terhadap Ekspresi Budaya Tradisional Indonesia. Disertasi Program Doktor Ilmu Hukum Universitas Diponegoro.

\section{INTERNET}

Garamfalvi, A.(2007).Ethiopian Coffee Trademark Dispute with the Starbucks Runs Hot and Cold. Retrieved from https://www.law.com/
almID/900005475658/?slreturn=2019032711 5727)

Geographical Indication and TRIPS: 10 yearsLater. Retrievedfromhttp://trade.ec.europa.eu/doclib /docs/2007/june/tradeoc_135088.pdf ,accesed on February 28201

Escudero, S. (2019). International Protection of Geographical Indication and Developing Countries. Retrievedfromhttp://www.southcent re.org, accesed on Februari 142019.

\section{REGULATION}

The Law No.20 of 2016 concerning Trademark and Geographical Indication; Governance Ordinance No. 51 of 2007.

Lisbon Agreement 1958 for the protection of Appellations of Origin and their International Registration.

Madrid Agreement 1891 for The Repression of False or Misleading Indications of Source Goods.

Paris Convention 1883 For Protection Industrial Property. 